\title{
Impact Of Coronavirus On Total Share In All Company Sectors In Indonesia Stock Exchange
}

\author{
An Suci Azzahra ${ }^{1 *}$, Ayu Wirdha Ningsih ${ }^{2}$ \\ ${ }^{1}$ Accounting Study Program, Politeknik Unggul LP3M, Jl.Iskandar Muda Nomor 3, Merdeka, Kec. Medan Baru, \\ Kota Medan, Sumatera Utara 20156 \\ ${ }^{2}$ Tax Accounting Study Program, Politeknik Unggul LP3M, Jl.Iskandar Muda Nomor 3, Merdeka, Kec. Medan Baru, \\ Kota Medan, Sumatera Utara 20156 \\ ${ }^{*}$ Corresponding Author: \\ Email: ansuciazzahra72@gmail.com*
}

\begin{abstract}
.
The purpose of this study is to analyze the impact of the coronavirus on total shares in all company sectors on the Indonesia Stock Exchange. This study examines whether there are differences in total shares before and after Covid-19 was announced in Indonesia. The data consists of total shares on January 31, 2020 (30 days before the announcement of COVID-19) and total shares on March 31, 2020 (30 days after the announcement of COVID-19) for all company sectors on the IDX. The method used is descriptive quantitative. The analysis technique in this study consists of descriptive statistics and hypothesis testing using the nonparametric MANOVA method on the STATCAL software. The results showed that there was a significant difference in the total shares before and after the announcement of the first case of covid-19 in Indonesia in sectors 1 , $3,4,6,7,8$, and 9, indicated by a significant value per company sector in all sectors $<0,05$, while for sectors 2 and 5 there is no significant difference. The value of the permutation test p-value is 0.01 , i.e. $<0.05$ level of significance, it can be concluded that overall, there is a significant difference in total shares 30 days before and after the announcement of COVID-19.
\end{abstract}

Keywords: covid-19, Total Shares, nonparametric MANOVA.

\section{INTRODUCTION}

Corona Virus is declared by the international organization in the health sector, namely the World Health Organization, which can cause humans to get sick in the respiratory tract. The term Coronavirus is also known as Covid-19 for its scientific name. This type of virus can threaten human safety because this virus can provide ranging from mild flu effects to serious stages more than the MERS-CoV and SARS-CoV viruses [1].The Ministry of Health of the Republic of Indonesia stated that the initial detection of Covid-19 was in China, precisely in Wuhan City on December 30, 2019. The contents of the information notification from the ministry were "immediate notification of pneumonia treatment from unknown causes". Since the announcement of this information and news spread on social media, it has also spread throughout the world regarding Covid-19 and has turned into a horror pandemic for the world community [2]. The Wuhan City Government has decided to lock down so that the virus does not spread, but the coronavirus outbreak has caused it to spread to various countries from January to February 2020. The coronavirus has spread to 50 countries with a total of 83,625 positive cases with a total of 2,858. recorded deaths as of 28 February 2020 [3].The impact of the Covid-19 outbreak has affected the world economy as seen in capital market activities. The impact of the Covid-19 event is an external non-economic event on the capital market. The beginning of 2020 until the end of the year is a very bad year for activities in the capital market [3].The spread of the coronavirus has an impact on the Indonesian economy. Indonesia has imposed restrictions on going out of the house so that many certain economic sectors have been negatively affected by the virus. Several companies have laid off [4].

The reaction of investors in responding to information is influenced by the amount of information contained in it, both information from internal and external companies. Events from internal conditions can be in the form of stock splits, issuance of financial statements, distribution of dividends, and other events. While external events can be economic or non-economic, such as legal, social, cultural, security, political events, and extraordinary events that cannot be predicted. [3].Investors invest their funds hoping to get a return. Return is the only way that makes sense for investors to compare various investment alternatives with various results from these investment alternatives [5]. Investing in the capital market, no one can be sure what will happen, if investors are interested and interested in investing in stocks during the COVID-19 
pandemic, investors should do 2 things, namely: (1) fundamental analysis of the shares to be purchased where fundamental analysis enables investors to know the company's prospects and predict future stock returns; (2) stock diversification where stock diversification will minimize the risk that will occur to investors [6]The high total shares traded are also an indicator that the company is performing well. The higher the number of shares traded indicates that investors have high confidence in transacting shares in the company. High total shares traded will move stock prices [7]. The higher the number of shares traded on the stock market, it indicates that investors believe in the company's performance, and the end, the stock price will increase. [8].The current Covid-19 pandemic has made the economic movement sluggish which resulted in a decline in people's income. This does not rule out the possibility, investors will be more selective in choosing a company as a place to invest which in the end will reduce the number of shares of the company traded. [7].

To maintain market conditions from continuing to decline, OJK and IDX issued several policies, such as reducing 1.5 hours of stock trading from normal trading hours that have been in effect since March 30,2020 , OJK also gave the Issuer the freedom to buy back shares without asking for prior approval in the process. GMS, Implemented a policy of pausing trading for 30 minutes in the event of a $5 \%$ decrease in intraday trading [9] Several previous studies related to the impact of the Covid-19 Pandemic on the total shares traded showed consistent research results. [4] found that after the Covid-19 Pandemic, there was a significant difference in the total traded shares studied in one company. Total shares traded were recorded higher after the Covid-19 Pandemic compared to before the Covid-19. [10] research results show that there are significant differences in stock trading volumes before and during Covid-19 in manufacturing companies in the consumer goods industry sector, as well as the results of [7] research on hotel, restaurant, and tourism companies. [11] also stated the results of the same study that the announcement of the first case of the Corona Virus in food and beverage companies contained information that caused the capital market to react to the frequency of trading in terms of trading transaction activities. This research is motivated by previous research studies which showed the same results for different objects. The researcher sees that the total shares traded are the most important factor in the sustainability of the company's business as well as an indicator in determining the performance of a company so that this research is deemed necessary to be carried out. The phenomenon of the Covid-19 pandemic that has occurred to date will certainly have implications for the total traded shares in the company [7].

Economic conditions, regulatory changes, and trends in one stock sector can affect the fluctuations in the price of all the individual stocks in it. In this section, a description of the total number of companies listed on the Indonesia Stock Exchange from 9 corporate sectors is explained as many as 691 companies. The following is the distribution of companies by company subsector: 1. Agriculture sector 2. Basic Industry and chemicals sector 3. Consumer Goods Industry sector 4. Finance sector 5. Finance sector Infrastructure, Utilities And Transportation 6. Mining Sector 7. Miscellaneous Industry Sector 8. Property, Real Estate and Building Construction Sector 9. Trade, Service and Investment Sector [12]The specific purpose of this study is to find out how the impact of the coronavirus on the total stock before and after the announcement of the Corona Virus in all corporate sectors on the IDX. How does the impact of the coronavirus on stock prices compare between one company sector and another ? The literature study was conducted by analyzing inline journals relevant to the research topic. This research is limited only to finding out which company sector has survived during the COVID-19 pandemic. Observations were made on the total shares on the regular market, before the announcement of covid-19 on January 31, 2020, and after the announcement of covid-19 on March 31, 2020. The selection of the period was based on the consideration that the COVID-19 pandemic was first discovered in Indonesia in early March 2020. The study uses secondary data from the Financial Services Authority, the Indonesia Stock Exchange, and IDX Monthly Statistics [12].

\section{II. 'METHODS}

This type of research is a comparative study because the study was conducted by comparing the total shares of the company sector traded before and after the first case of the coronavirus was announced.The population in this study are all companies listed on the Indonesia Stock Exchange with a total of 691 companies. The sample in this study was determined using the purposive sampling technique. NonProbability Sampling is a sampling technique that does not provide equal opportunities or opportunities for each element or member of the population to be selected as a sample. This sampling technique includes systematic sampling, quota, accidental, purposive, saturated, snowball. In this study, the sampling technique used is non-probability sampling with purposive sampling technique. 


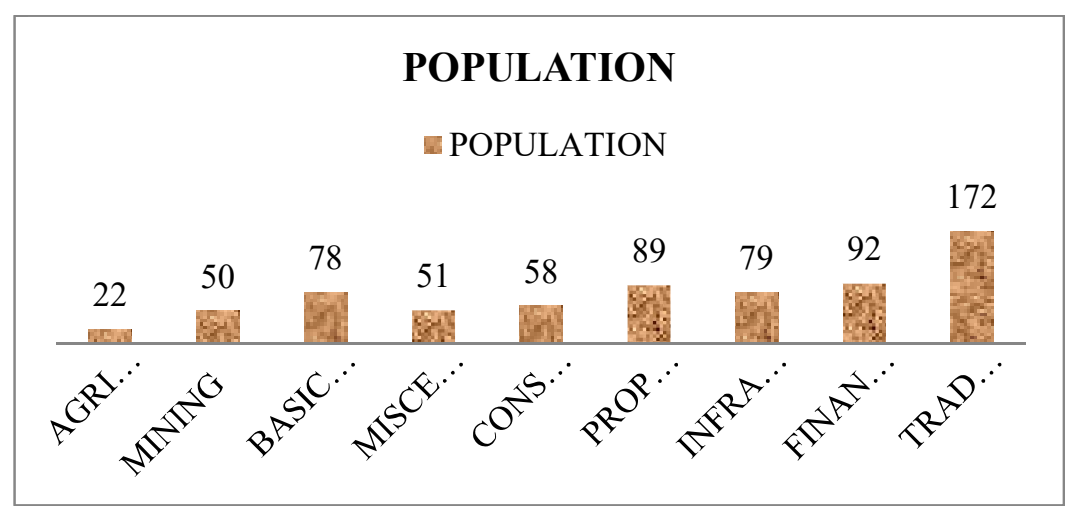

Fig 1. Total Company Population per Company Sector

Table 1. Population and Sample Data

\begin{tabular}{|c|l|c|c|c|}
\hline $\begin{array}{c}\text { NO } \\
\text { SECTOR }\end{array}$ & \multicolumn{1}{|c|}{ SECTOR NAME } & POPULATION & NS & SAMPLE \\
\hline 1 & AGRICULTURE & 22 & 2 & 20 \\
\hline 2 & MINING & 50 & 8 & 42 \\
\hline 3 & BASIC INDUSTRY AND CHEMICALS & 78 & 4 & 74 \\
\hline 4 & MISCELLANEOUS INDUSTRY & 51 & 4 & 47 \\
\hline 5 & CONSUMER GOODS INDUSTRY & 58 & 8 & 50 \\
\hline 6 & $\begin{array}{l}\text { PROPERTY, REAL ESTATE, AND BUILDING } \\
\text { CONSTRUCTION }\end{array}$ & 89 & 15 & 74 \\
\hline 7 & $\begin{array}{l}\text { INFRASTRUCTURE, UTILITIES, AND } \\
\text { TRANSPORTATION }\end{array}$ & 79 & 9 & 70 \\
\hline 8 & FINANCE & 92 & 4 & 88 \\
\hline 9 & TRADE, SERVICE, AND INVESTMENT & 172 & 19 & 153 \\
\hline & & 691 & 73 & 618 \\
\hline
\end{tabular}

The data used in this study are secondary data obtained through the website www.idx.com. The data consists of the total shares seen on the regular market on January 31, 2020 (30 days before the announcement of COVID-19) and March 31, 2020 (30 days after the announcement of COVID-19) for all companies on the IDX.

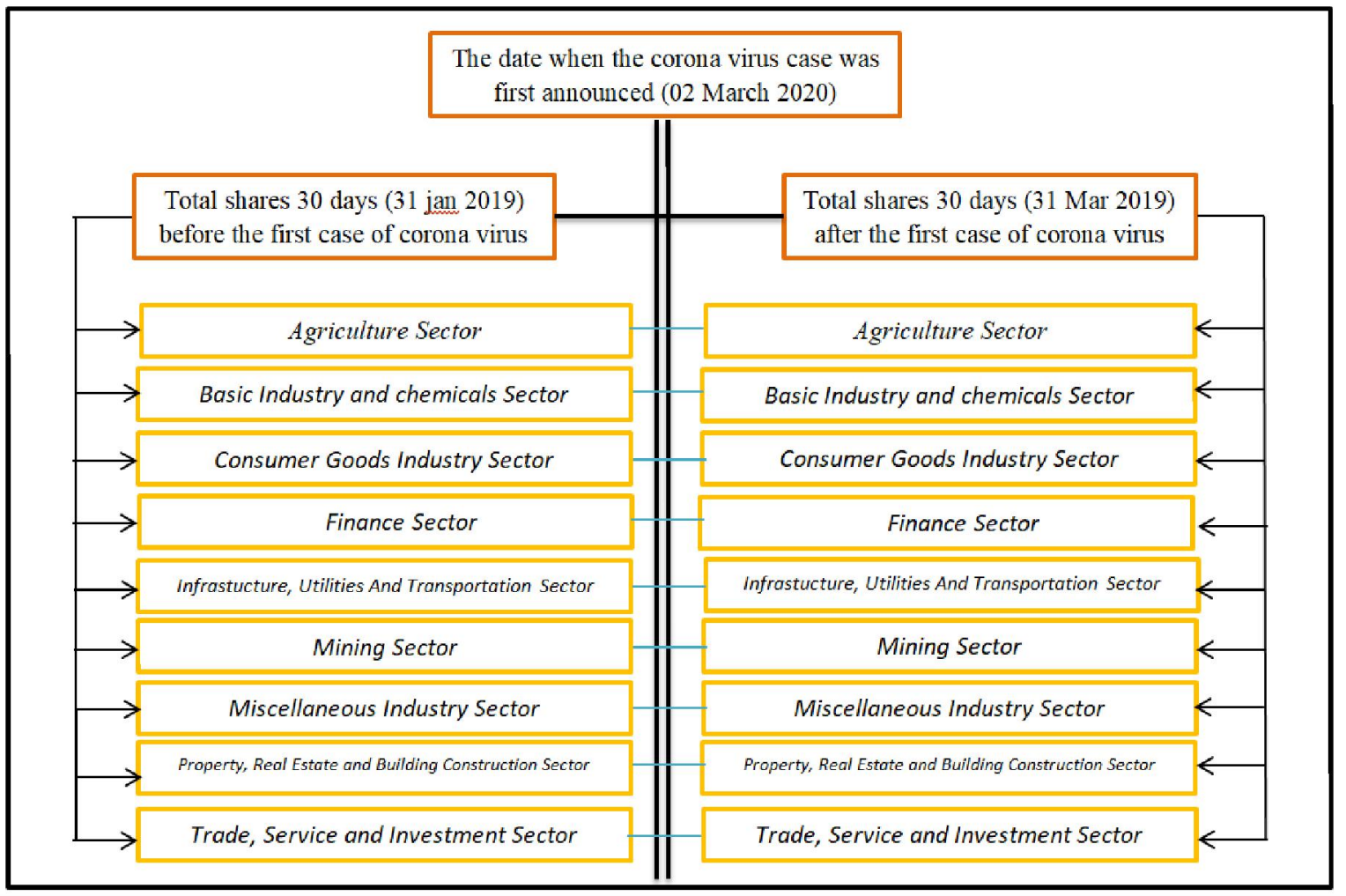

Fig 2. Theoretical Thinking Framework 


\section{RESULT AND DISCUSSION \\ Descriptive Analysis}

In this section, we will explain the situation of Total Shares before and during COVID-19 based on 9 company sectors. Figure 3 shows the average value of Total Shares, using Total Shares data for 9 company sectors, before and after Covid-19 was announced.

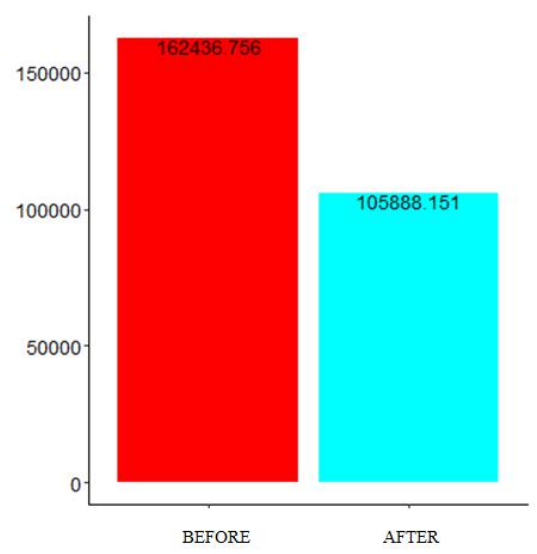

Fig 3. Average Total Shares Before and After COVID-19 Announced

It can be seen that on average there has been a decrease in Total Shares after COVID-19 was announced. Figure 4 presents the average Total Shares based on 9 company sectors before and when (after) COVID-19 was announced. While Figure 5 presents the percentage of the average difference in Total Shares based on 9 company sectors after COVID-19 was announced.

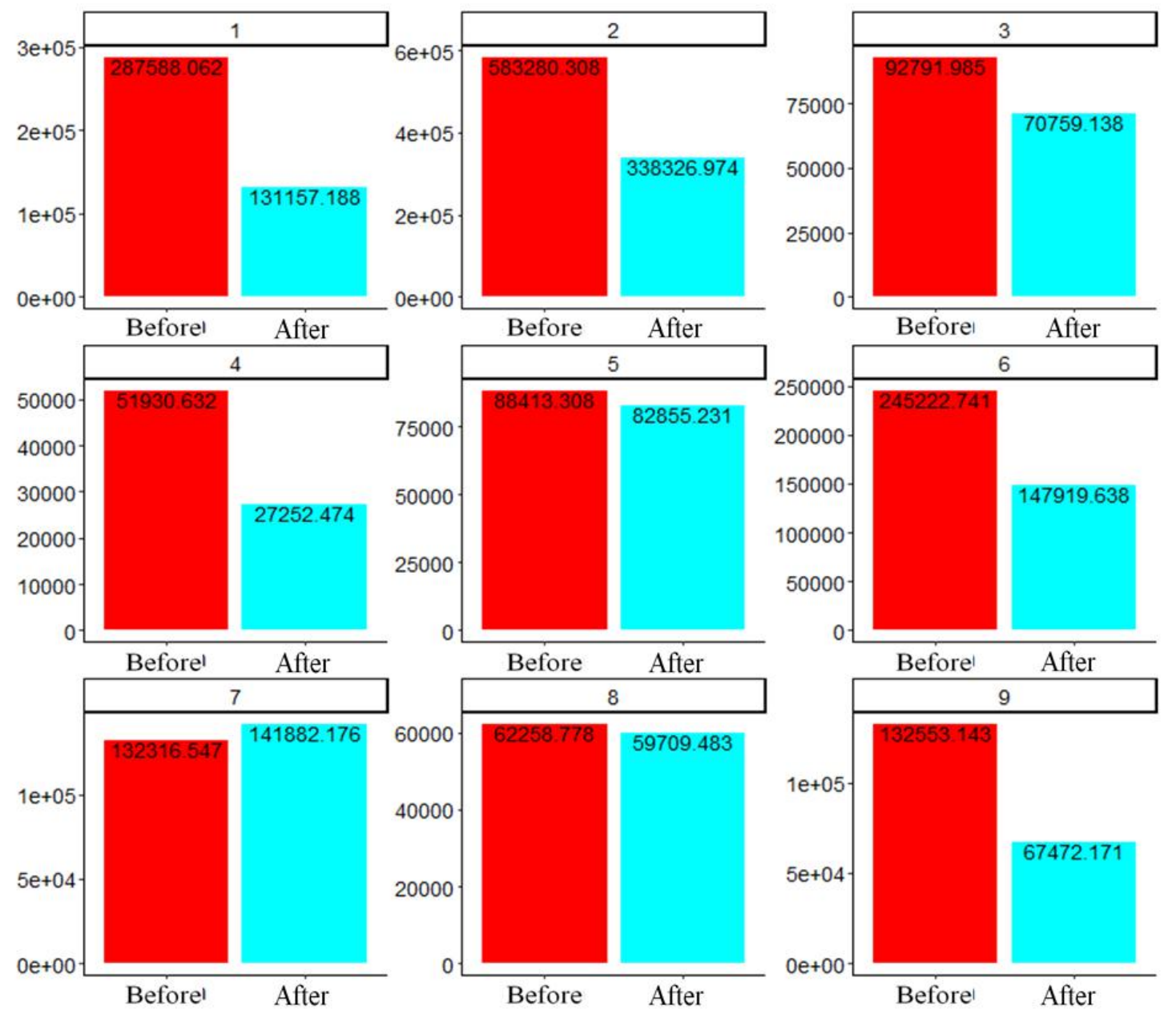

Fig 4. Average Total Shares by 9 Sectors 


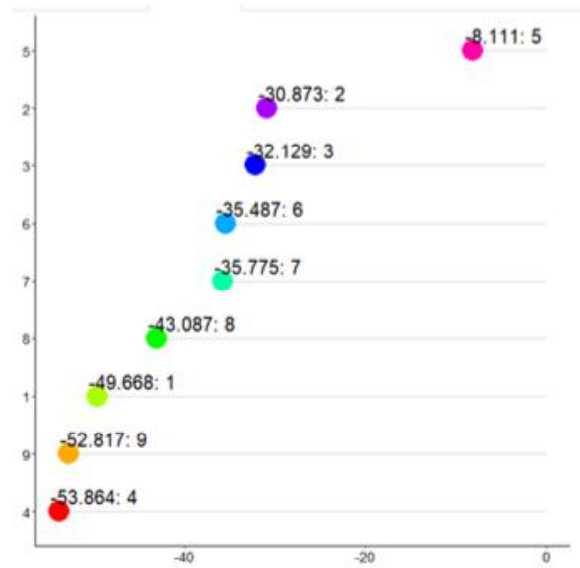

Companies Before and After COVID-19 was announced

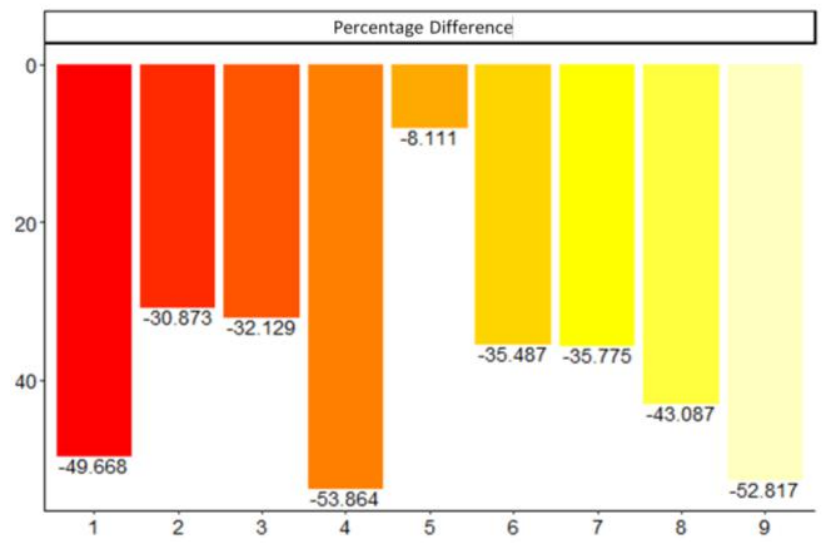

Fig 5. Percentage of Average Difference in Total Shares

Based on 9 Company Sectors After COVID-19 was announced

Based on Figure 4, it can be seen that after COVID-19 was announced, on average there was a decrease in Total Shares from 9 company sectors. In Figure 5, it can be seen that on average the highest decline in Total Shares occurred in the 4th company sector after COVID-19 was announced. The 5th corporate sector was, on average, the least affected after COVID-19 was announced.

\section{Effect of COVID-19 on Total Stocks by 9 Company Sectors}

Furthermore, it will be tested whether there is a significant difference in Total Shares before and after COVID-19 was announced, based on 9 company sectors.

\section{Hypothesis testing}

The nonparametric Wilcoxon test method was used to test whether there was a significant difference in Total Shares before and after COVID-19 was announced, based on 9 company sectors.

Table 2. Wilcoxon Test: Significance Test for Differences in Total Shares Before and After COVID-19 was announced in 9 Company Sectors

\begin{tabular}{cc}
\hline Comparison & P-Value of Wilcoxon Test \\
\hline 1: Before vs After covid announcement & 0.01825 \\
\hline 2: Before vs After covid announcement & 0.07501 \\
3: Before vs After covid announcement & 0.00162 \\
4: Before vs After covid announcement & 0.00001 \\
\hline 5: Before vs After covid announcement & 0.21426 \\
6: Before vs After covid announcement & 0.00768 \\
7: Before vs After covid announcement & 0.01684 \\
8: Before vs After covid announcement & 0.00094 \\
9: Before vs After covid announcement & 0.00000 \\
\hline
\end{tabular}

Based on the results of the Wilcoxon test in Table 2, it is known that there were significant total shares, before and during (after) COVID-19 was announced, in sectors 1, 3, 4, 6, 7, 8, and 9, while for sectors 2 and 5 it was not significant. 
Nonparametric Multivariate Analysis of Variance: Effect of COVID-19 on Stock Prices based on 9 Company Sectors

Furthermore, it will be tested whether there is a significant difference in stock prices before and after COVID-19 was announced, based on 9 company sectors. The nonparametric multivariate analysis of variance (nonparametric MANOVA) method was used to test whether there was a significant difference in stock prices 30 days before and after the COVID-19 announcement, based on 9 company sectors.STATCAL software was used in this study because the nonparametric MANOVA method is available in the STATCAL software [13]. MANOVA nonparametric method in STATCAL software using R name . package [14] The nonparametric MANOVA does not use the assumption of multivariate normality. Table 3 presented the results of the nonparametric MANOVA.

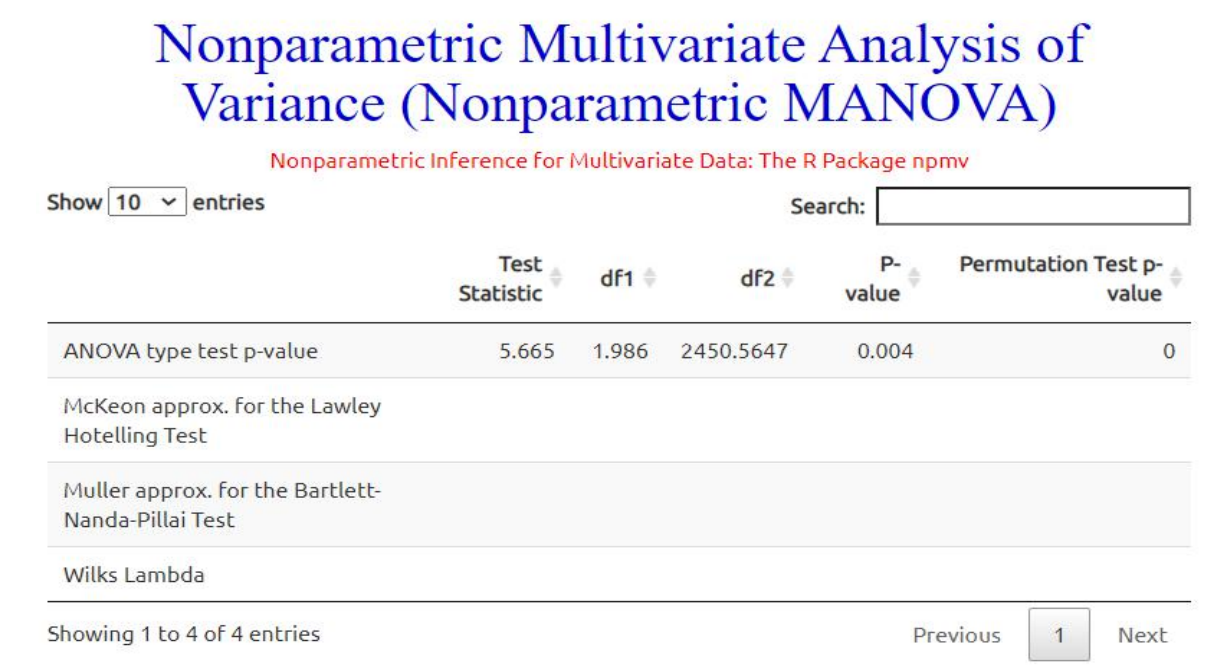

Fig 6. Nonparametric MANOVA with Statcal Software

Table 3. Nonparametric MANOVA: The Effect of COVID-19 on Total Stocks by 9 Company Sectors

\begin{tabular}{cc}
\hline Comparison & P-Value \\
\hline $\begin{array}{c}\text { Before vs After covid } \\
\text { announcement }\end{array}$ & $\mathrm{P}=0.000$ \\
\hline
\end{tabular}

Based on the nonparametric MANOVA results in Table 4, it is known that the permutation test $\mathrm{p}$ value is 0.01 , i.e. < the significance level of 0.05 , it can be concluded that overall, there is a significant difference in total shares 30 days before and after the announcement of COVID-19, based on 9 corporate sectors. In other words, COVID-19 has a significant effect on total shares based on 9 company sectors.Based on the previous description, it can be seen that the 4th sector was most heavily affected by the decline in total shares after COVID-19 was announced, while the 5th sector was the least affected by the decrease in total shares after COVID-19 was announced.

\section{CONCLUSION}

The impact of the coronavirus on total shares before and after Covid-19 was announced in each company sector, significantly sector $1,3,4,6,7,8$, and 9 companies were very influential as seen from the results of the Wilcoxon test all probability values $<0.05$, which means there is a significant difference in total shares, 30 days before and after the announcement of COVID-19. Meanwhile, sectors 2 and 5 have no significant effect.The impact of the coronavirus on total shares before and after Covid-19 was announced in all company sectors was significantly very influential, as seen from the results of the Nonparametric MANOVA test, the permutation test $p$-value was 0.01 , i.e. $<0.05$ significance level.It was found that the 4 th company in the Miscellaneous Industry sector decreased in value by $53.86 \%$, the 9th Trade, Service And Investment decreased in value by $52.81 \%$ and the 1 st Agriculture sector decreased in value by $49.66 \%$ experienced a total decline shares that before and after Covid-19 was announced.It was found that companies in the 5th position in the Consumer Goods Industry sector were the least affected by a decrease in stock prices of $8.11 \%$. 


\section{ACKNOWLEDGMENTS}

The authors thank the member authors. In addition, the authors would like to express special thanks to the Director of Research and Community Service (DRPM) who has provided research funding support through the novice lecturer research grant program.

\section{REFERENCES}

[1] J. M. Kirigia and R. N. D. K. Muthuri, "The fiscal value of human lives lost from coronavirus disease (COVID19) in China," BMC Res. Notes, vol. 13, no. 1, pp. 1-5, 2020.

[2] D. A. D. Nasution, Erlina, and I. Muda, "Dampak Pandemi COVID-19 terhadap Perekonomian Dunia," J. Ekon. Perjuangan, vol. 2, no. 2, pp. 212-224, 2021.

[3] E. K. Agustiawan and E. Sujana, "Reaksi Pasar Modal Indonesia Sebelum Dan Sesudah Pengumuman Kebijakan Pemerintah Tentang Status Darurat Bencana Covid-19,” J. Akunt. Profesi, vol. 1, no. 2, pp. $293-$ 302,2020 .

[4] I. Nurmasari, "Dampak Covid-19 Terhadap Perubahan Harga Saham dan Volume Transaksi (Studi Kasus Pada PT. Ramayana Lestari Sentosa, Tbk.)," J. SEKURITAS (Saham, Ekon. Keuang. dan Investasi), vol. 3, no. 3, p. 230, 2020.

[5] G. R. J. Charles P. Jones, Investment: Analysis and Management, 14th ed. America: Wiley eBook, 2019.

[6] D. Tambunan, "Investasi Saham di Masa Pandemi," Widya Cipta J. Seretari Dan Manaj., vol. 4, no. 2, pp. 117-123, 2020.

[7] S. Siswantoro, "Efek diumumkannya kasus pertama Covid-19 terhadap harga saham dan total saham yang diperdagangkan,” J. Akunt. Keuang. dan Manaj., vol. 1, no. 3, pp. 227-238, 2020.

[8] I. Indarti and D. M. B. Purba, "Analisis Perbandingan Harga Saham Dan Volume Perdagangan Saham Sebelum Dan Sesudah Stock Split Dalam Perspektif Ekonomi Islam,” J. Ilm. Aset, vol. 13, no. 1, pp. 57-63, 2011.

[9] H. T. Putri, "Covid 19 dan Harga Saham Perbankan di Indonesia," Eksis J. Ilm. Ekon. dan Bisnis, vol. 11, no. 1, p. 6, 2020.

[10] S. Muzdalifah, Maslichah, and Afifudin, "Perbandingan Harga Saham dan Volume Perdagangan Saham Sebelum dan Saat Covid-19 pada Perusahaan Manufaktur Yang Terdaftar Di Bursa Efek Indonesia," E-Jra, vol. 10, no. 01, pp. 22-31, 2021.

[11] I. B. Sambuari, I. S. Saerang, and J. B. Maramis, "Reaksi Pasar Modal Terhadap Peristiwa Virus Corona (Covid-19) Pada Perusahaan Makanan Dan Minuman Yang Terdaftar Di Bursa Efek Indonesia," JMBI UNSRAT (Jurnal Ilm. Manaj. Bisnis dan Inov. Univ. Sam Ratulangi)., vol. 7, no. 2, pp. 407-415, 2020.

[12] www.idx.co.id.

[13] P. U. Gio and R. E. Caraka, Belajar Mengolah Data dengan STATCAL Disertai Perbandingan Hasil dengan Software. Medan, Indonesia, 2021.

[14] A. R. Ellis, W. W. Burchett, S. W. Harrar, and A. C. Bathke, "Nonparametric inference for multivariate data: The R package name," J. Stat. Softw., vol. 76, no. 1, 2017. 